ARTICLE

https://doi.org/10.1038/s41467-020-18808-8

\title{
Dissolved black carbon is not likely a significant refractory organic carbon pool in rivers and oceans
}

Yuanzhi Qi ${ }^{1}$, Wenjing Fuํ, Jiwei Tian ${ }^{2}$, Chunle Luo ${ }^{1}$, Sen Shan ${ }^{1}{ }^{1}$, Shuwen Sun ${ }^{3}$, Peng Ren ${ }^{1,3}$, Hongmei Zhang ${ }^{1}$, Jiwen Liu (1) ${ }^{4}$, Xiaohua Zhang (10 ${ }^{4} \&$ Xuchen Wang (1) ${ }^{1,3 凶}$

Rivers are the major carriers of dissolved black carbon (DBC) from land to ocean; the sources of DBC during its continuous transformation and cycling in the ocean, however, are not well characterized. Here, we present new carbon isotope data for DBC in four large and two small mountainous rivers, the Yangtze and Yellow river estuaries, the East China Sea and the North Pacific Ocean. We found that the carbon isotope signatures of DBC are relatively homogeneous, and the $\mathrm{DBC}{ }^{14} \mathrm{C}$ ages in rivers are predominantly young and increase during continuous transport and cycling in the ocean. The results of charcoal leaching experiments indicate that $D B C$ is released from charcoal and degraded by bacteria. Our study suggests that riverine $D B C$ is labile and respired during transport and mixing into the ocean and that residual DBC is cycled and aged on the same time scales as bulk DOC in the ocean.

\footnotetext{
${ }^{1}$ Key Laboratory of Marine Chemistry Theory and Technology, Ministry of Education/ Center for Frontier Science of Deep Ocean and Earth System, Ocean University of China, Qingdao, China. ${ }^{2}$ Key Laboratory of Physical Oceanography, Ocean University of China, Qingdao, China. ${ }^{3}$ Center for Isotope Geochemistry and Geochronology, Qingdao National Laboratory for Marine Science and Technology, Qingdao, China. ${ }^{4}$ Key Laboratory of Marine Genetics and Breeding, College of Marine Life Sciences, Ocean University of China, Qingdao, China. ${ }^{凶}$ email: xuchenwang@ouc.edu.cn
} 
$\mathrm{B}$ lack carbon (BC), a common residue of incomplete combustion of biomass and fossil fuel, is widely dispersed in soils and marine sediments ${ }^{1,2}$. Defined as a group of condensed byproduct chemicals, BC is thought to be chemically stable and hardly biodegradable ${ }^{3,4}$, thus representing a refractory fraction of organic carbon (OC), and its role in the global carbon cycle and its environmental impacts have received considerable attention $^{2,5-8}$. In recent years, several studies have reported that dissolved $\mathrm{BC}(\mathrm{DBC})$ could represent a significant fraction of $\mathrm{BC}$ mobilized and transported by rivers into the ocean ${ }^{9-12}$. World rivers are estimated to carry $27 \mathrm{Tg} \mathrm{yr}^{-1}$ of DBC, which accounts for approximately $10 \%$ of the global flux of dissolved OC (DOC) via rivers ${ }^{12}$. The amount of river transported $\mathrm{DBC}$ is also equipollent to the particulate $\mathrm{BC}$ ( $\mathrm{PBC}$ ) transported by rivers worldwide $\left(17-37 \mathrm{Tg} \mathrm{yr}^{-1}\right)^{6}$. Together, the annual transport of DBC and PBC by rivers could account for $8-60 \%$ of the annual production of $\mathrm{BC}$, thus representing a dominant source of $\mathrm{BC}$ input into the oceans. Globally, it is estimated that the production of $\mathrm{BC}$ is dominated by biomass burning (114-383 $\mathrm{Tg} \mathrm{yr}^{-1}$ ), which is one to two orders of magnitude higher than the amount of BC produced from fossil fuel combustion $\left(2-29 \mathrm{Tg}^{-1}\right)^{6}$. In their recent study, Jones et al. ${ }^{13}$ estimated that $60 \mathrm{Pg}$ of $\mathrm{BC}$ (or pyrogenic carbon) has been produced cumulatively since 1750 from landscape fires, accounting for $33-40 \%$ of the global biomass carbon lost through land use and deforestation in the same time period ${ }^{13}$. This carbon-rich charcoal can be stored in soils and oceans over very long time periods ${ }^{2,14}$, thus representing a significant, but overlooked, sink for atmospheric $\mathrm{CO}_{2}{ }^{13}$. Although the size of $\mathrm{DBC}$ exported by rivers is still a relatively small fraction of the DOC pool in the global carbon cycle and budget, its geochemical importance is thought to be significant due largely to its stable chemical structure, resistance to microbial degradation ${ }^{15,16}$, and long residence time as a major sink of atmospheric $\mathrm{CO}_{2}$ in the global carbon cycle ${ }^{10,11,17,18}$

The sources and fate of DBC in the natural aquatic environment have not been well constrained due mainly to the lack of a well-recognized and consensus standard separation and the quantification method ${ }^{19,20}$. The chemothermal oxidation (CTO) method has been used as a popular isolation technique to determine BC in environmental samples ${ }^{21-23}$. This method determines mainly highly condensed aromatic compounds of $\mathrm{BC}^{20}$. In recent years, benzene polycarboxylic acids (BPCAs) have also been used as molecular proxies to quantify $\mathrm{DBC}$, mainly polycyclic aromatic compounds, in both rivers and oceans ${ }^{9-11,24,25}$. Despite the different techniques used, the abundances of DBC reported by the two methods show high similarity in both river and oceanic waters $9,17,24-26$.

Radiocarbon $\left({ }^{14} \mathrm{C}\right)$ measurement has been used as a powerful tool to distinguish the sources of DBC produced from biomass burning and fossil fuel combustion because these two sources have distinct ive ${ }^{14} \mathrm{C}$ ages (modern vs. ancient) ${ }^{2,9-11}$. The $\mathrm{DBC}$ isolated from rivers has been found to have relatively modern ${ }^{14} \mathrm{C}$ ages ${ }^{9,26}$, while the ${ }^{14} \mathrm{C}$ ages of DBC in the ocean are extremely old $(>20,000 \text { years })^{10,11}$. These studies raised some important questions that have not been answered. Why are the ${ }^{14} \mathrm{C}$ ages of DBC so different in rivers and oceans if world rivers are the major pathways of transporting and exporting DBC from land to ocean? Could the extremely aged ${ }^{14} \mathrm{C} \mathrm{DBC}$ in the ocean suggest that $\mathrm{DBC}$ has been cycled for a much longer time than the bulk DOC in the ocean? In a recent study, Wagner et al. ${ }^{24}$ measured the stable carbon isotopes of $\mathrm{DBC}$ in rivers and oceans. They found large differences in the $\delta^{13} \mathrm{C}$ compositions of $\mathrm{DBC}$ that were more depleted (by $-6 \%$ ) in rivers than in the ocean. They concluded that oceanic $\mathrm{DBC}$ is unlikely to be sourced from riverine $\mathrm{DBC}$, thus making the oceanic DBC story even more enigmatic. If the majority of $\mathrm{DBC}$ in the ocean is not from river inputs, can we determine another possible major source that contributes DBC to the ocean? Our current understanding of the sources and cycling of DBC in the ocean is based on a few studies that seem contradictory rather than consistent.

Here, we report new carbon isotope $\left(\Delta^{14} \mathrm{C}\right.$ and $\left.\delta^{13} \mathrm{C}\right)$ results for DBC isolated by solid phase extraction (SPE) from four major rivers in China (Yangtze, Yellow, Pearl, and Heilongjiang rivers) and two small mountainous rivers in Taiwan (Dadu and Tamsui), as well as DBC isolated from the Yangtze and Yellow river estuaries, the East China Sea (ECS) and the Mariana Trench site in the western North Pacific (NP). In addition, long-term ( $\sim 1700$ days) locust tree wood charcoal leaching experiments were conducted to determine the dissolution of DBC from charcoal in river water with and without bacteria and to assess the possible biodegradation of DBC. These data provide new insight for our understanding of the source, biodegradability, and cycling time scales of DBC in rivers and oceans.

\section{Results}

Concentrations of DOC and DBC in rivers and oceans. Sampling locations are summarized in Supplementary Table 1, and the concentrations and isotope data are listed in Supplementary Table 2. The concentrations of DOC in the rivers showed large variations, ranging from 62 to $1072 \mu \mathrm{M}$. On average, DOC concentrations were comparable in the Yangtze $(138 \pm 65 \mu \mathrm{M})$, Yellow $(210 \pm 45 \mu \mathrm{M})$, Pearl $(84 \pm 4 \mu \mathrm{M})$, and Taiwan rivers $(216 \pm 11$ $\mu \mathrm{M})$ but much higher in the Heilongjiang River $(857 \pm 337 \mu \mathrm{M})$ (Fig. 1a). For the monthly samples in the lower Yellow River, DOC concentrations were lower in May and June $(123-131 \mu \mathrm{M})$ during the high flow period but were quite consistent in the other months of 2015. DOC concentrations were higher in the Yellow River Estuary $(250 \pm 4 \mu \mathrm{M})$ than in the Yangtze River Estuary $(168 \pm 25 \mu \mathrm{M})$ and decreased gradually from the Yangtze River Estuary to the ECS $(89 \pm 21 \mu \mathrm{M})$. At the Mariana Trench site in the western NP, DOC concentrations decreased from $76 \pm 2 \mu \mathrm{M}$ in the upper $100 \mathrm{~m}$ to $39 \pm 1 \mu \mathrm{M}$ at great depths $(8000-10,000 \mathrm{~m})$ (Fig. 1a).

The SPE extraction efficiencies of DOC also showed great variations from river to ocean waters, ranging from 40 to $76 \%$ (Supplementary Table 2). Overall, the SPE extraction efficiencies of DOC were higher for river water $(61 \pm 6 \%)$ than for estuarine and coastal waters $(51 \pm 11 \%)$ and open ocean waters $(47 \pm 4 \%)$. These results are consistent with the values reported in recent studies using the same SPE method ${ }^{9,24}$. DBC contents measured in the SPE-DOC also showed variations in the rivers, and the average $\mathrm{DBC} / \mathrm{DOC}$ ratios were $3.7 \pm 1.5 \%$ in the Yangtze River, $4.8 \pm 3.6 \%$ in the Yellow River, $7.5 \pm 0.1 \%$ in the Pearl River, $0.9 \pm$ $0.5 \%$ in the Heilongjiang River, and $7.6 \pm 1.1 \%$ in the Taiwan rivers. The Heilongjiang River had the highest DOC but the lowest $\mathrm{DBC} / \mathrm{DOC}$ ratio $(0.9 \pm 0.5 \%)$. For the monthly Yellow River samples, it appeared that the DBC/DOC ratios were relatively lower (1.2-2.6\%) during winter months (January, November, and December) and high flow months (1.9-3.6\%, May-July) than during the other months (Supplementary Table 2). The average $\mathrm{DBC} / \mathrm{DOC}$ ratios were $4.0 \pm 0.8 \%$ in the Yangtze River Estuary, $4.7 \pm 0.4 \%$ in the Yellow River Estuary, $2.9 \pm 1.2 \%$ in the ECS, and $2.6-6.8 \%$ in the deep water of the Mariana Trench site in the NP (Fig. 1b).

Isotopic signatures of DOC, SPE-DOC, and DBC in rivers and oceans. The DOC $\delta^{13} \mathrm{C}$ values showed a wide range from -21.0 to $-29.0 \%$ in the rivers. On average, DOC in the Heilongjiang River had a more depleted $\delta^{13} \mathrm{C}$ value $(-28.5 \pm 0.4 \%$ ) than DOC in the Taiwan $(-27.5 \pm 0.2 \%$ ) , Pearl $(-26.5 \pm 0.4 \%$ ), Yangtze $(-26.5 \pm 1.0 \%$ ) , and Yellow $(-24.6 \pm 2.0 \%$ ) rivers (Fig. 1c). The 

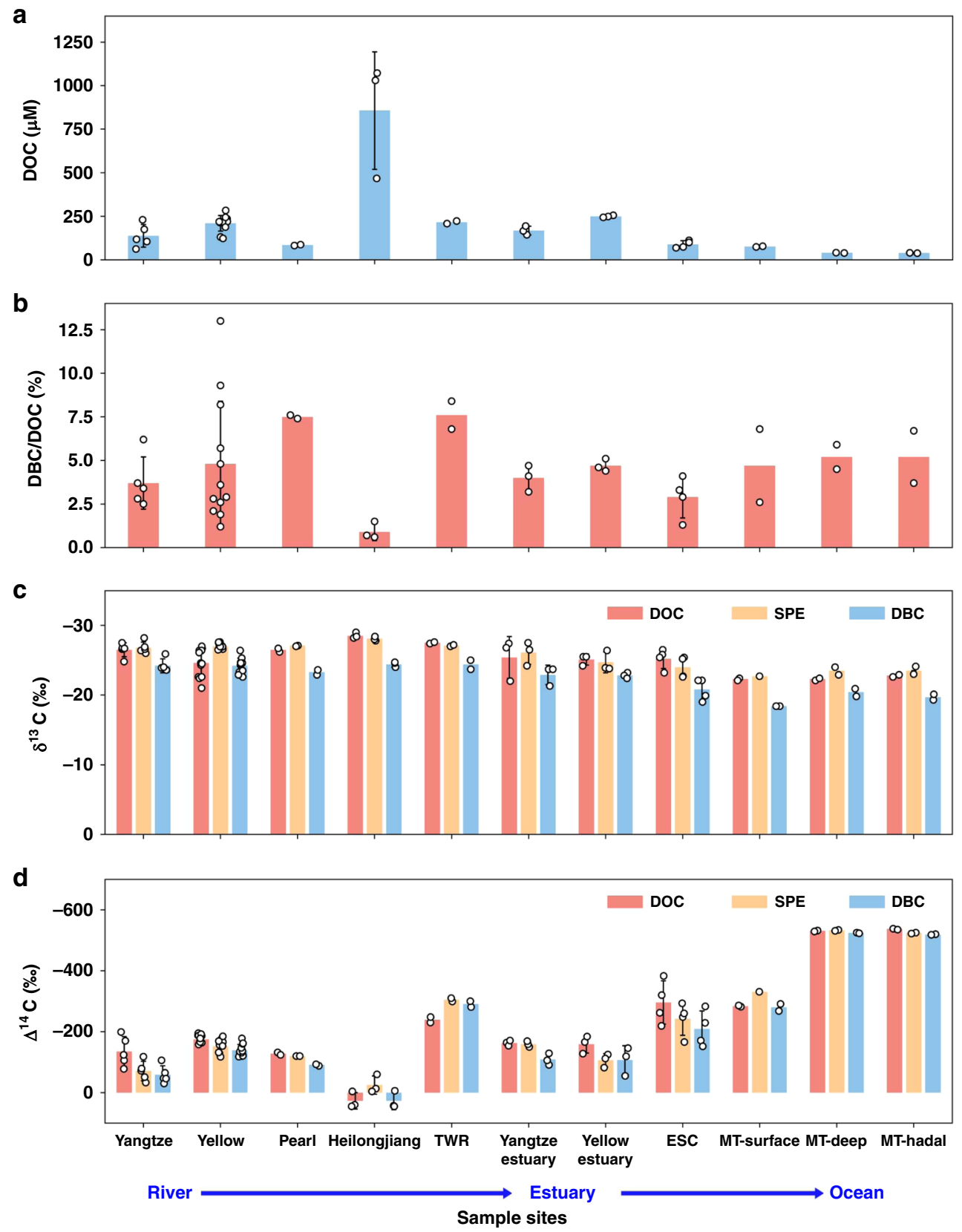

Fig. 1 Distribution of the concentrations and isotopic compositions. a The concentrations of DOC, b DBC/DOC ratios, $\mathbf{c}$ the $\delta^{13} \mathrm{C}$ values, and $\mathbf{d}$ the $\Delta^{14} \mathrm{C}$ values of DOC, SPE-DOC, and DBC in the Yangtze $(n=5)$, Yellow $(n=12)$, Heilongjiang $(n=3)$, Pearl $(n=2)$, and Taiwan rivers (TWR, $n=2)$, the Yangtze River Estuary $(n=3)$, the Yellow River Estuary $(n=3)$, the East China Sea (ECS) $(n=4)$, and the Mariana Trench (MT) site in the North Pacific (NP) ( $n=2$ MT-surface, $n=2$ MT-deep, $n=2$ MT-hadal) (DOC dissolved organic carbon, SPE-DOC solid phase extracted dissolved organic carbon, DBC dissolved black carbon). The bar charts are the means and the error bars are the calculated standard deviations (SD) of the data group (for $n \geq 3$ ). The black circles are corresponding data points.

Yellow River monthly DOC $\delta^{13} \mathrm{C}$ values also showed large variation, ranging from -21.0 to $-27.0 \%$. The DOC $\delta^{13} \mathrm{C}$ values were on average $-25.4 \pm 3.0 \%$ in the Yangtze River Estuary, $-25.1 \pm 0.8 \%$ in the Yellow River Estuary, $-25.2 \pm 1.4 \%$ in the ECS, and -22.1 to $-23.1 \%$ at the Mariana Trench site in the NP. In contrast, the $\delta^{13} \mathrm{C}$ values of SPE-DOC in each river were mainly comparable with the bulk DOC $\delta^{13} \mathrm{C}$ values for most samples and were also quite constant in each river, especially for the Yellow River monthly samples. The average $\delta^{13} \mathrm{C}$ values of SPE-DOC were $-26.8 \pm 0.8 \%$ in the Yangtze River, $-27.8 \pm$ $0.4 \%$ in the Yellow River, $-27.0 \pm 0.1 \%$ in the Pearl River, $-28.1 \pm 0.3 \%$ in the Heilongjiang River, and $-27.1 \pm 0.1 \%$ in the
Taiwan rivers (Fig. 1c). The $\delta^{13} \mathrm{C}$ values of SPE-DOC were $-26.1 \pm 1.7 \% 0$ and $-24.7 \pm 1.5 \%$ in the Yangtze River and Yellow River estuaries, respectively, $-24.0 \pm 1.5 \%$ in the ECS, and $-22.7 \%$ at the surface $(50-100 \mathrm{~m})$ and $-23.5 \pm 0.8 \%$ in the deep depths $(3000-10,000 \mathrm{~m})$ at the Mariana Trench site. These samples showed no significant differences when compared with bulk DOC $\delta^{13} \mathrm{C}$ values. The $\delta^{13} \mathrm{C}$ values of $\mathrm{DBC}$ ranged from $-22.6 \%$ to $-26.4 \%$ in the rivers and -21.3 to $-23.7 \%$ in the estuaries, $-20.8 \pm 1.6 \%$ in the ECS and $-18.4 \%$ to $-20.9 \%$ in the Mariana Trench site, which are considerably higher than the $\delta^{13} \mathrm{C}$ values of both DOC and SPE-DOC in the rivers and oceans. As plotted in Fig. 1c, the average $\mathrm{DBC} \delta^{13} \mathrm{C}$ value was enriched by 
3-4\% compared to those of DOC and SPE-DOC, which was the most notable systematic change in $\mathrm{DBC} \delta^{13} \mathrm{C}$ signatures.

Large variations were found in $\Delta^{14} \mathrm{C}$ values among the samples. The DOC $\Delta^{14} \mathrm{C}$ values ranged from 45 to $-248 \%$ in the rivers, -154 to $-184 \%$ in the estuaries, -219 to $-383 \%$ in the ECS, and -282 to $-538 \%$ at the Mariana Trench site in the NP. The corresponding ${ }^{14} \mathrm{C}$ ages spanned from modern to 6180 years before present (YBP). On average, the $\Delta^{14} \mathrm{C}$ values of DOC were $-135 \pm 50 \%$ in the Yangtze River, $-175 \pm 15 \%$ o in the Yellow River, $-130 \pm 5 \%$ o in the Pearl River and $-240 \pm 10 \%$ in the Taiwan rivers. The monthly DOC $\Delta^{14} \mathrm{C}$ values in the Yellow River were slightly higher in the high flow season (May-July) but were mostly consistent across months in 2015. The DOC in the Heilongjiang River, however, had a modern $\Delta^{14} \mathrm{C}$ value of $27 \pm$ $27 \%$ o (Fig. 1d). The average DOC $\Delta^{14} \mathrm{C}$ values were $-160 \pm 10 \%$ and $-159 \pm 29 \%$ in the Yangtze River and Yellow River estuaries, $-295 \pm 70 \%$ in the ECS and $-284 \pm 2 \% 0,-531 \pm 2 \%$, and $-537 \pm 2 \%$ in the surface, deep and hadal depths at the Mariana Trench site (Fig. 1d). The ${ }^{14} \mathrm{C}$ age of DOC in the depths $(8000-10,000 \mathrm{~m})$ of the Mariana Trench site was $\sim 6100$ years. In contrast, the $\Delta^{14} \mathrm{C}$ values of SPE-DOC in the Yangtze $(-70 \pm$ $30 \%$ ), Yellow $(-150 \pm 20 \%$ ) , and Pearl $(-120 \pm 1 \%$ ) rivers were slightly higher (or younger) than those of DOC but slightly lower (older) than those of DOC in the Heilongjiang $(-25 \pm 30 \%)$ and Taiwan rivers $(-305 \pm 10 \%)$. The SPE-DOC $\Delta^{14} \mathrm{C}$ had values similar to those of DOC in the Yangtze River Estuary $(-160 \pm$ $10 \%$ ), were higher in the Yellow River Estuary $(-106 \pm 22 \%$ ) and the ECS $(-240 \pm 50 \%$ o $)$ and were comparable to those of DOC in the Mariana Trench of the NP $(-331,-533$, and $-524 \%$ ) (Fig. 1d).

The $\Delta^{14} \mathrm{C}$ values of $\mathrm{DBC}$ also showed notable variations (Fig. 1d). The average DBC $\Delta^{14} \mathrm{C}$ values were $-60 \pm 30 \%$ in the Yangtze River, $-140 \pm 20 \%$ in the Yellow River and $-91 \pm 3 \%$ o in the Pearl River, which were $30-65 \%$ o higher $(\sim 200-500$ years younger) than those of DOC and slightly higher than those of SPE-DOC (Fig. 1d). For the Yellow River, the DBC $\Delta^{14} \mathrm{C}$ values in each month were all higher than the $\Delta^{14} \mathrm{C}$ values of DOC (by $6-77 \%$ o). The DBC $\Delta^{14} \mathrm{C}$ value was modern $(27 \pm 29 \%$ ), the same as that of DOC in the Heilongjiang River, and $-290 \pm 10 \%$ o $(50 \%$ lower or 350 years older) relative to those of DOC in the two small mountainous rivers in Taiwan. The DBC $\Delta^{14} \mathrm{C}$ values in the Yangtze River Estuary $(-110 \pm 20 \%$ ), Yellow River Estuary $(-107 \pm 47 \%)$, and the ECS $(-210 \pm 60 \%$ ) were also significantly higher (by $50 \%$ o to $85 \%$ o) or younger (by $\sim 350-660$ years) than those of DOC. At the Mariana Trench site in the NP, the DBC $\Delta^{14} \mathrm{C}$ values on average were $-80 \pm 20 \%$ in the surface water $(50-100 \mathrm{~m}),-524 \pm 1 \%$ o in the deep $(3000-6000 \mathrm{~m})$ and $-519 \pm 1 \%$ in the hadal $(8000-10,000 \mathrm{~m})$ waters. The values showed almost no differences from those of DOC (Fig. 1d).

Leaching and biodegradation of DBC. The results of the longterm charcoal leaching experiments are plotted in Fig. 2. It can be seen that significant DBC was released and dissolved in DOC from the charcoal in the bacteria-inhibited case (Fig. 2a). It appeared that two steps were involved in the charcoal release processes: the first release took place in the first 100 days, with an increase of approximately $70 \mu \mathrm{M}$ DOC, and the second release took place after 250 days, with $550 \mu \mathrm{M}$ DOC measured at 1000 days $(\sim 322 \mu \mathrm{M}$ DOC increase from the initial $228 \mu \mathrm{M})$. The locust tree wood charcoal was $\mathrm{C}$-rich, and its $\mathrm{C} \%$ was measured at $80 \%$. We calculated that $2.4 \%$ of the charcoal $\mathrm{C}$ was dissolved in the DOC on day 1000. At the end of the experiment, the DOC concentration was measured for $440 \mu \mathrm{M}$ in the bacteria-inhibited case, a $20 \%$ decrease from the highest level of $550 \mu \mathrm{M}$. In comparison, for the significant difference in the bacteria-active leaching case, the DOC concentration actually decreased by $17 \%$ after 150 days from the initial 228 to $188 \mu \mathrm{M}$ and then remained unchanged to the end of the experiment (Fig. 2a). No DBC accumulation was observed in the bacteria-active water.

The bacterial abundance measured in the bacteria-active water was much higher $\left(3.58 \times 10^{5} \mathrm{cell} \mathrm{mL}^{-1}\right)$ than that in the bacteriainhibited water $\left(0.28 \times 10^{5}\right.$ cell $\left.\mathrm{mL}^{-1}\right)$ at the end of the experiments (Fig. 2b). The bacterial abundance was $4.63 \times 10^{5}$ cell $\mathrm{mL}^{-1}$ in the Yellow River water measured as the reference (Fig. 2b). For DOC isotopic values, the $\Delta^{14} \mathrm{C}$ and $\delta^{13} \mathrm{C}$ values were measured at -170 and $-25.1 \%$ in the bacteria-active water and -90 and $-27.8 \%$ in the bacteria-inhibited water at the end of the experiments, and these values were compared with the initial DOC $\Delta^{14} \mathrm{C}$ and $\delta^{13} \mathrm{C}$ values of -166 and $-24.6 \%$ of the Yellow River water, respectively (Fig. 2c).

\section{Discussion}

For the samples we studied, we found a very good linear correlation $\left(R^{2}=0.99, p<0.001\right)$ between the concentrations of SPEDOC with DOC in the river, coastal and ocean waters (Fig. 3a). This strong linear relationship could suggest an interesting phenomenon that, regardless the differences in DOC concentrations and the sample locations, the SPE method using the PPL cartridges likely extracted the same organic materials that were proportionally dissolved in DOC in natural waters. This fraction of SPE-DOC could have similar chemical properties such as molecular weight, composition and polarity ${ }^{9,24,26}$. In contrast, the DBC concentrations isolated in SPE-DOC also had a linear but relatively weak correlation $\left(R^{2}=0.45, p<0.001\right)$ with DOC in the samples we studied (except for the Heilongjiang River). We think that this could be reasonable because the content of DBC, unlike the SPE-DOC fraction, is source-specific and should be largely controlled by the input of DBC source, while DOC could be derived from multiple sources such soil OC, biomass degradation and in situ production. The Heilongjiang River, for example, had the highest DOC concentrations $(857 \pm 337 \mu \mathrm{M})$ but much lower DBC contents $(0.9 \pm 0.5 \%)$ compared to other rivers. This could reflect relatively lower input of DBC in the less populated and cold northern climate with fewer landscape fires than the populated warm southern region with more biomass burning ${ }^{13}$. The lack of correlation between DBC and DOC concentrations has also been reported recently for the Amazon River and attributed to the divergent effects of soil properties, temperature, rainfall, and aerosol deposition on DOC and DBC mobilization from the catchments of tropical rivers ${ }^{9}$. Despite the different DBC isolation methods used, however, the DBC contents reported in the different rivers are in the comparable range of $4-10 \%$ in general. For example, based on the BPCA method, DBC has been reported to account for 7.0-9.9\% of riverine DOC in the Paraíba do Sul ${ }^{25}$ and Amazon ${ }^{9}$ rivers, $7.3 \%$ in the Mississippi River and $6.9-8.4 \%$ in the Congo River ${ }^{24}$, comparable to the values of $3.7-7.6 \%$ for the six rivers we determined using the CTO method. For the four large continental rivers in China that we studied, based on the average discharge rates, measured DOC concentration and DBC/ DOC ratio of each river, we calculated an annual flux of DBC of $5.5 \times 10^{10}, 3.5 \times 10^{9}, 2.2 \times 10^{10}$, and $1.1 \times 10^{10} \mathrm{~g}$ carried by the Yangtze, Yellow, Pearl, and Heilongjiang rivers, respectively. Together, $9.2 \times 10^{10} \mathrm{~g}$ of DBC was transported by these rivers. This flux accounts for only a very small fraction $(0.34 \%)$ of the $27 \mathrm{Tg}$ of global riverine DBC export estimated by ${ }^{12}$ and is only $3.4-4.8 \%$ of the annual DBC flux (1.9-2.7 Tg) estimated for the Amazon River, the largest river in the world, largely due to the high DOC and DBC concentrations in the river ${ }^{9}$.

The variable DBC contents we determined in the rivers could also reflect the seasonal variations because we collected our 
a

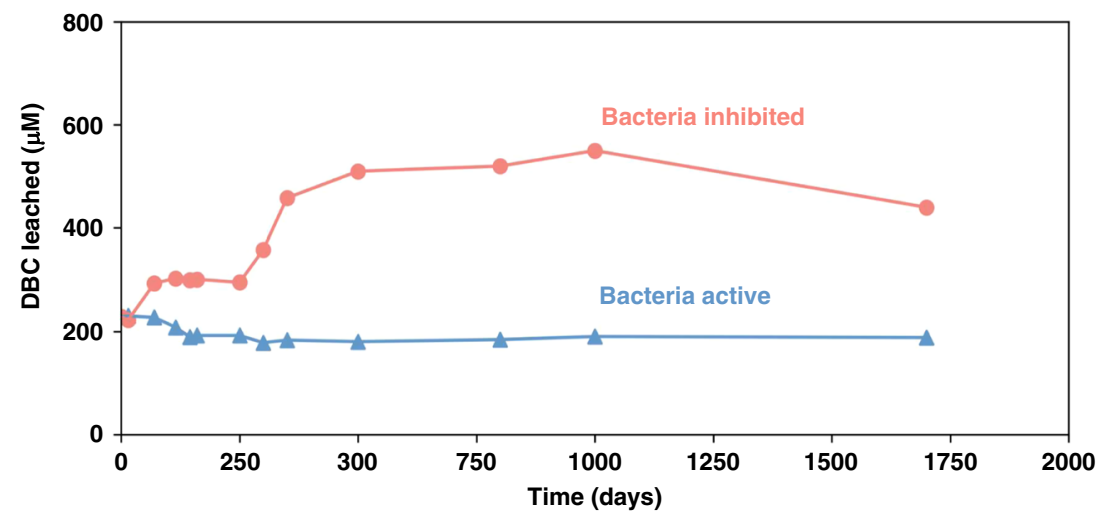

b
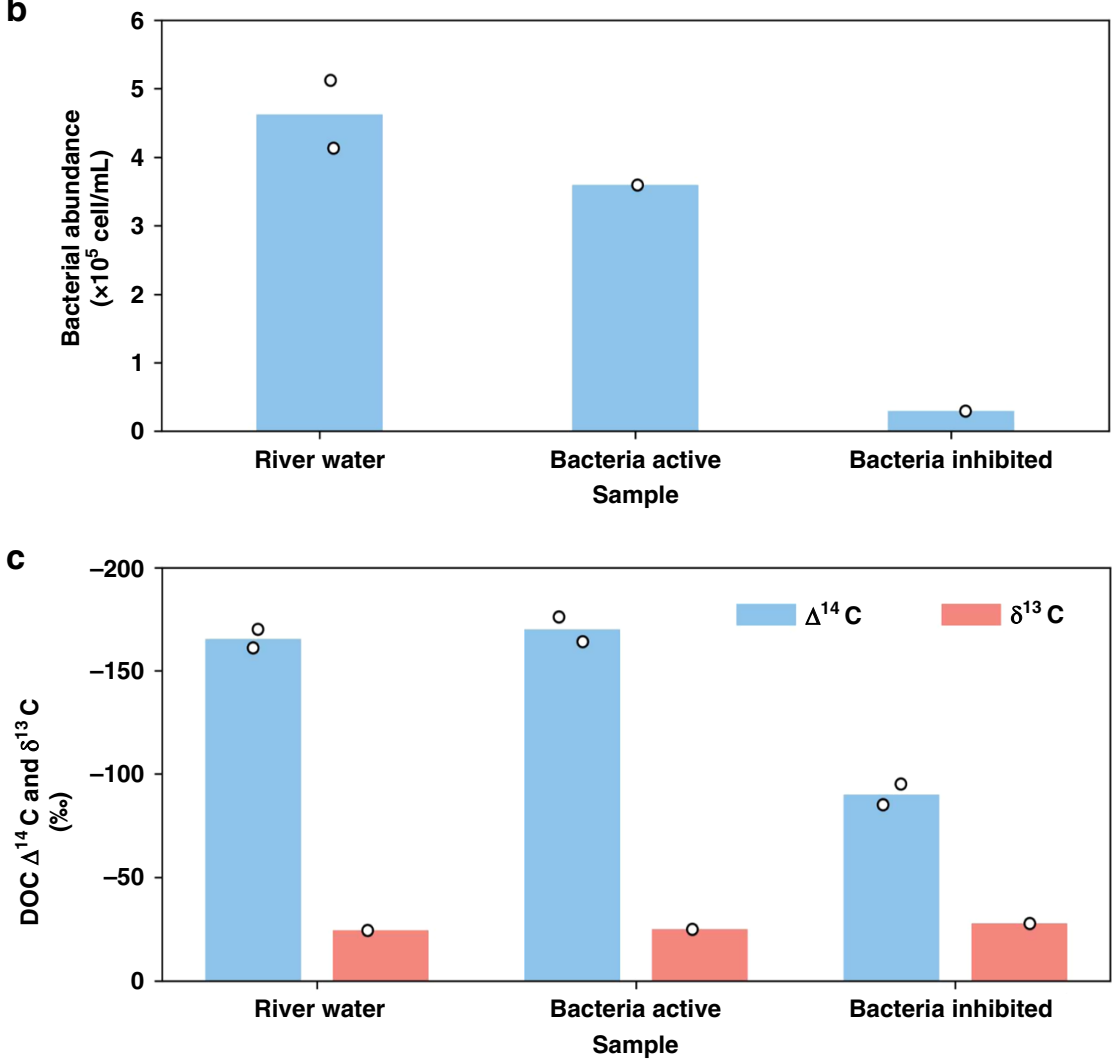

Fig. 2 Characteristics of DBC in the leaching experiments. a Long-term time incubation showing the leaching of DBC (dissolved black carbon), measured as DOC (dissolved organic carbon) concentrations from charcoal in both bacteria-active and bacteria-inhibited river waters during the 1700-day incubation period; $\mathbf{b}$ bacterial abundance, and $\mathbf{c} \Delta^{14} \mathrm{C}$ and $\delta^{13} \mathrm{C}$ values of DOC measured in the river water and bacteria-active and bacteria-inhibited river waters at the end of the experiments. The bar charts are the average values of the duplicate measurements (true value for single point measurement). The black circles are corresponding data points.

samples during different seasons and years. This could be demonstrated by the monthly samples of the Yellow River. In general, lower DBC/DOC rations were measured in the winter months (January, November, and December) and summer months (June and July), with more rain precipitation and a relatively high flow rate 26 . This could suggest that the cold and frozen temperature in the winter in the lower Yellow River drainage region can reduce the release and dissolution of DBC from charcoal preserved in soils. On the other hand, more precipitation could dilute the DBC concentrations in the river. For most of the year, the $\mathrm{DBC}$ content was within the range of the other world rivers $9,24,25$

For DBC in the ocean, a relatively large range of $\mathrm{DBC} / \mathrm{DOC}$ has been reported in different studies. Using the BPCA method,
Wagner et al. ${ }^{24}$ reported that very low DBC abundance accounted for $0.8-1.8 \%$ of the DOC in the Pacific and Atlantic oceans, while using the same method, Coppola and Druffel ${ }^{10}$ and Lewis et al. ${ }^{27}$ reported relatively higher DBC contents, accounting for $4.2-8.6 \%$ of the DOC in the Atlantic, Pacific, and Arctic oceans, which are comparable to the values we obtained in the ECS $(2.9 \pm 1.2 \%)$ and the Mariana Trench site in the western NP (2.6-6.8\%).

The isotopic signatures of DOC, SPE-DOC, and DBC we studied for the various samples provide more insight for the transport and cycling of these different OC materials in rivers and oceans. As shown in Fig. 4, we see strong linear correlations for the plots of $\Delta^{14} \mathrm{C}$ values among DOC, SPE-DOC, and DBC. Good positive correlations exist between the $\Delta^{14} \mathrm{C}$ values of $\mathrm{DOC}$ vs. SPE-DOC (Fig. 4a, $R^{2}=0.90, p<0.0001$ ), DOC vs. DBC (Fig. $4 \mathrm{~b}$, 

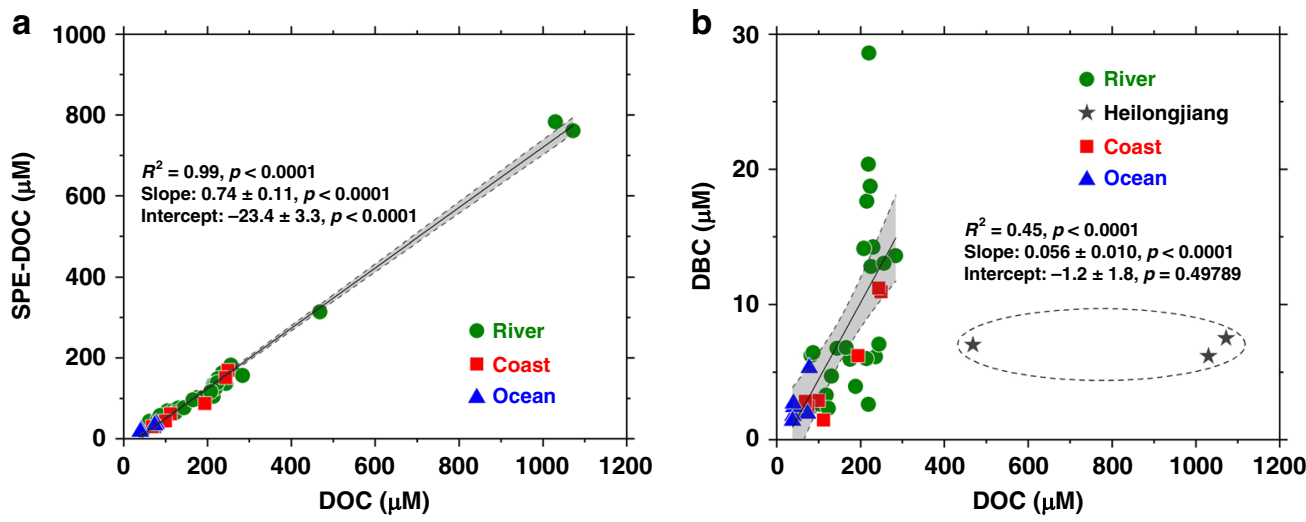

Fig. 3 Correlations of SPE-DOC and DBC with DOC. a Concentrations of SPE-DOC vs. DOC for all samples determined $\left(n=40, R^{2}=0.99, p<0.0001\right)$; and $\mathbf{b}$ concentrations of DBC vs. DOC for the samples ( $n=37, R^{2}=0.45, p<0.0001$, Heilongjiang data were not included) (DOC dissolved organic carbon, SPE-DOC solid phase extracted dissolved organic carbon, DBC dissolved black carbon). The statistics are for the regression of the average values. The gray areas show the $95 \%$ confidence interval of the linear regression. We applied one-sided $F$ test and two-sided $t$ test, and the calculated $p$ values as shown.

$R^{2}=0.92, p<0.0001$ ), and SPE-DOC vs. DBC (Fig. $4 \mathrm{c}, R^{2}=0.97$, $p<0.0001)$. These strong correlations suggest that DOC, SPEDOC, and DBC have systematic covariances in terms of their $\Delta^{14} \mathrm{C}$ values, and DBC was coupled with DOC and aged on the same time scales during transport from river to coast and open oceans. In the four rivers we studied, the ${ }^{14} \mathrm{C}$ ages of riverine $\mathrm{DBC}$ are all younger (modern to 1510 years, except in the two small mountainous rivers in Taiwan) than the ${ }^{14} \mathrm{C}$ ages of $\mathrm{DOC}$ (modern to 1720) especially in the Yangtze and Pearl rivers, consistent with the results reported for the Amazon River ${ }^{9}$. The relatively younger ${ }^{14} \mathrm{C}$ ages of $\mathrm{DBC}$ in the rivers suggest that riverine $\mathrm{DBC}$ is mainly sourced from biomass burning rather than fossil fuel combustion. In our previous study, we calculated based on a two end-member isotope mass balance model that $78-85 \%$ of the DBC transported in the Yangtze and Yellow rivers was derived from biomass burning ${ }^{26}$. Regardless of the monthly variations of DBC contents in the Yellow River, their ${ }^{14} \mathrm{C}$ ages $(1143 \pm 180)$ had less variation, supporting the source-specific input of $\mathrm{DBC}$ in the river. The same calculation reveals that 83 and $100 \%$ of the riverine DBC transported in the Pearl and Heilongjiang rivers and $65 \%$ of DBC in the Taiwan mountainous rivers are derived from biomass burning. The DBC was dissolved over time from the charcoal preserved in soils and entered waters in streams and rivers ${ }^{12,25,28}$. The older DBC in the Taiwan mountain rivers could suggest that some charcoals were preserved in soil for longer amounts of time. In contrast, the riverine DBC ${ }^{14} \mathrm{C}$ ages are distinctively different than the $\mathrm{PBC}$ transported in rivers. Our previous study showed that $\mathrm{PBC}$ transported in the Yangtze and Yellow rivers had ${ }^{14} \mathrm{C}$ ages of 4550 and 5830 years, respectively, as derived mainly from fossil fuel combustion ${ }^{26}$. For 18 global rivers, it was reported that the average $\mathrm{PBC}{ }^{14} \mathrm{C}$ age was $3700 \pm 400$ years, much older than the ${ }^{14} \mathrm{C}$ age of $\mathrm{DBC}$ in the rivers ${ }^{6}$.

Very few ${ }^{14} \mathrm{C}$ measurements of oceanic DBC have been reported in the literature. Ziolkowski and Druffel ${ }^{11}$ reported the first ${ }^{14} \mathrm{C}$ measurement of $\mathrm{DBC}$ isolated by ultrafiltration in the Atlantic and Pacific oceans. The ${ }^{14} \mathrm{C}$ ages of $\mathrm{DBC}$ were $15,680-18,300$ years old in the Atlantic and 17,000-20,100 years old in the Pacific, much older than the bulk DOC ${ }^{14} \mathrm{C}$ ages of $4000-6000$ years in the 2 oceans $^{29,30}$. More recently, using SPEDOC isolation, Coppola and Druffel ${ }^{10}$ reported that the ${ }^{14} \mathrm{C}$ ages of DBC were $4800 \pm 620$ years in the surface water and 23,000 \pm 3000 years in the deep water of the Arctic, Atlantic, and Pacific oceans. They concluded that DBC in the ocean is not homogeneous; one younger DBC pool is cycling on centennial time scales, and one ancient DBC pool is cycling on $>10^{5}$-year time scales $^{10}$. The isotopic signatures of DBC in the ocean determined in our study, however, are sometimes inconsistent with these previous findings. For DBC in the oceans, we found that the average ${ }^{14} \mathrm{C}$ ages were $1835 \pm 616$ years in the ECS; $2570 \pm 184$ years in the surface water; and $5900 \pm 14$ years and $5820 \pm 28$ years in the deep waters $(3000-6000 \mathrm{~m})$ and hadal depth (8000-10,000 $\mathrm{m})$ at the Mariana Trench site in the NP, respectively. The $\mathrm{DBC}{ }^{14} \mathrm{C}$ ages were all younger than the bulk DOC ${ }^{14} \mathrm{C}$ ages in the Yangtze River and Yellow River estuaries, and the ECS, and approximately the same as the $\mathrm{DOC}{ }^{14} \mathrm{C}$ ages in the surface water and slightly younger in the deep waters at the Mariana Trench site. Based on these results, we speculate that $\mathrm{DBC}$ in the ocean was transported and aged during its cycling through rivers and estuaries to coastal and open oceans in a continuum process coupled with DOC. DBC is likely cycled and aged on the same time scales as the bulk DOC pool in the ocean. Meanwhile, we remain puzzled about the DBC age differences found between our study and previous studies. It is possible that the age difference could be due to the CTO and BPCA methods used, which could have determined different organic compounds with very different ${ }^{14} \mathrm{C}$ signatures. The relatively consistent $\Delta^{14} \mathrm{C}$ values of DBC we determined for the monthly samples in the Yellow River did suggest that we isolated the same materials. This age inconsistency is certainly an important question that needs to be further investigated.

Unlike their $\Delta^{14} \mathrm{C}$ signatures, the correlations between the $\delta^{13} \mathrm{C}$ values of DOC and SPE-DOC (Fig. $4 \mathrm{~d}, R^{2}=0.23, p<0.01$ ), DOC and DBC (Fig. $4 \mathrm{e}, R^{2}=0.31, p<0.001$ ) are weak. In comparison, the correlation between SPE-DOC and DBC $\delta^{13} \mathrm{C}$ values is much better (Fig. $4, R^{2}=0.75, p<0.0001$ ). This was due to the variable ranges of DOC $\delta^{13} \mathrm{C}$ values $(-21.0$ to $-29.0 \%$ ) in the rivers we studied. Since $\delta^{13} \mathrm{C}$ in DOC is mainly an OC source indicator, the variable DOC $\delta^{13} \mathrm{C}$ values in the rivers indicate that DOC was derived from different sources. For DOC in the Heilongjiang River, for example, it was mainly derived from the leaching and degradation of plant biomass with modern ${ }^{14} \mathrm{C}$ ages. Its DOC $\delta^{13} \mathrm{C}$ values ( -28.2 to $-29.0 \%$ o) were consistent and significantly depleted relative to the DOC $\delta^{13} \mathrm{C}$ values in the three large continental rivers, Yangtze, Yellow, and Pearl, where the sources of DOC were more complicated, including both natural and anthropogenic inputs ${ }^{31,32}$. As discussed above, the large variations of DOC $\delta^{13} \mathrm{C}$ values $(-21.0$ to $-27.0 \%$ ) measured in the Yellow River could reflect seasonal source variations of DOC, consistent with the weak correlation between DBC and DOC concentrations (Fig. 3b). In contrast to bulk DOC, the good correlations between SPE-DOC and DBC $\delta^{13} \mathrm{C}$ values (Fig. 4f) 

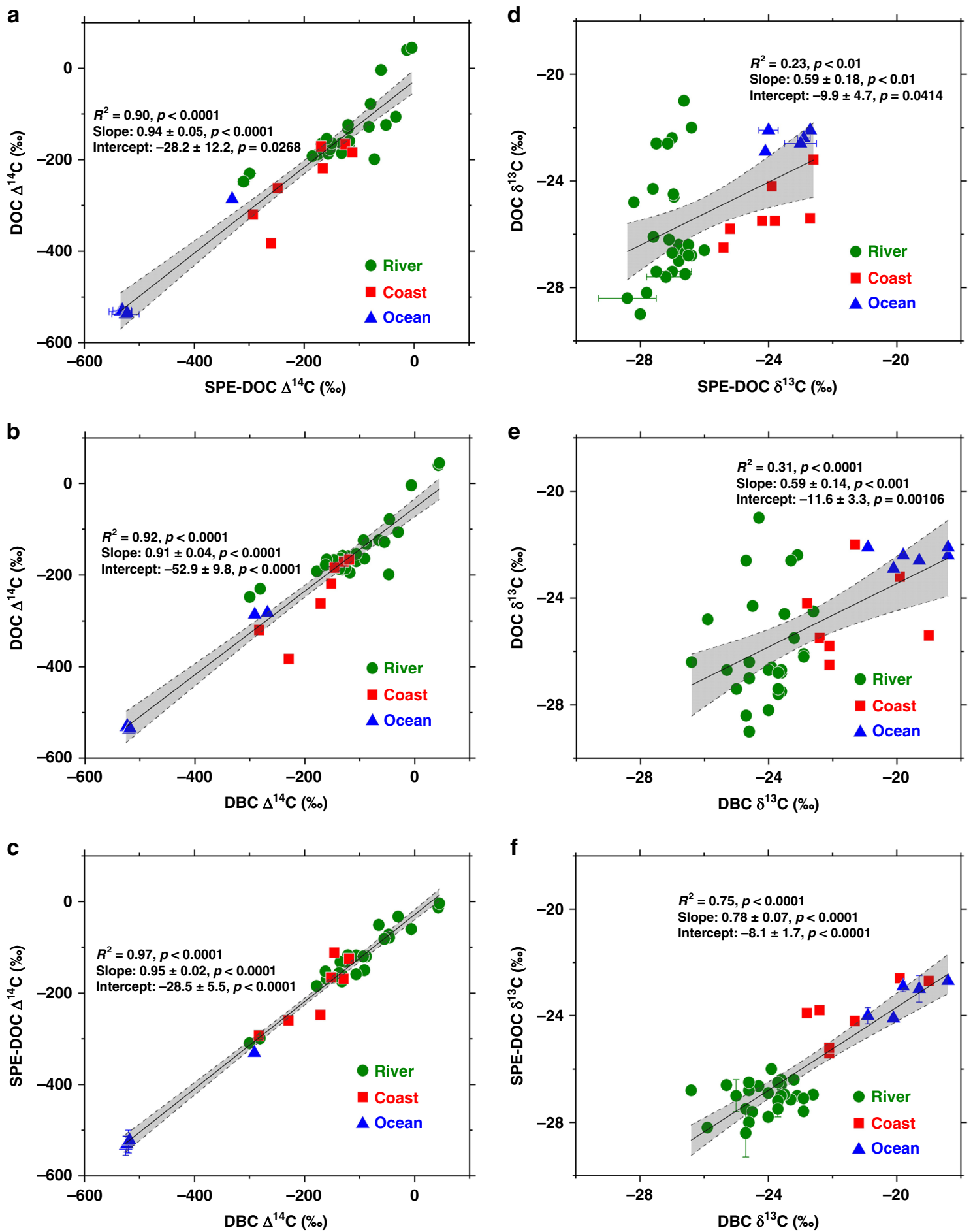

Fig. 4 Isotopic correlations between different carbon pools. a DOC $\Delta^{14} \mathrm{C}$ vs. SPE-DOC $\Delta^{14} \mathrm{C}(n=38)$, b DOC $\Delta^{14} \mathrm{C}$ vs. DBC $\Delta^{14} \mathrm{C}(n=40)$, c SPE-DOC $\Delta^{14} \mathrm{C}$ vs. DBC $\Delta^{14} \mathrm{C}(n=38)$; and $\mathbf{d} \mathrm{DOC} \delta^{13} \mathrm{C}$ vs. SPE-DOC $\delta^{13} \mathrm{C}(n=39)$, e DOC $\delta^{13} \mathrm{C}$ vs. DBC $\delta^{13} \mathrm{C}(n=40)$, and $\mathbf{f} \mathrm{SPE}-\mathrm{DOC} \delta^{13} \mathrm{C}$ vs. DBC $\delta^{13} \mathrm{C}(n=39)$ for the river, coastal and ocean samples (DOC dissolved organic carbon, SPE-DOC solid phase extracted dissolved organic carbon, DBC dissolved black carbon). The points with error bars are the average values of duplicate measurements and the error bars represent the range of the measured values. The statistics are for the regression of all data points. The gray areas show the $95 \%$ confidence interval of the linear regression. We applied one-sided $F$ test and two-sided $t$ test, and the calculated $p$ values as shown.

again suggests that these organic fractions are more sourcespecific than other organic fractions.

In our study, we also found that the $\mathrm{DBC} \delta^{13} \mathrm{C}$ values are all enriched (by $2-4 \%$ in general) relative to the $\delta^{13} \mathrm{C}$ values of bulk DOC and SPE-DOC in rivers, coastal waters and the open ocean (Fig. 1c). We examined the correlations between the ${ }^{14} \mathrm{C}$ ages and $\delta^{13} \mathrm{C}$ values of $\mathrm{DBC}$ for the samples (Fig. 5). A linear correlation $\left(R^{2}=0.52, p<0.0001\right)$ appears between $\mathrm{DBC}{ }^{14} \mathrm{C}$ ages and its $\delta^{13} \mathrm{C}$ values (except for the Taiwan river and deep ocean). When the $\mathrm{DBC}$ ages increase from the rivers to the ocean, its $\delta^{13} \mathrm{C}$ values become enriched. Riverine DBC has more depleted $\delta^{13} \mathrm{C}$ values than oceanic DBC. This phenomenon is consistent with 


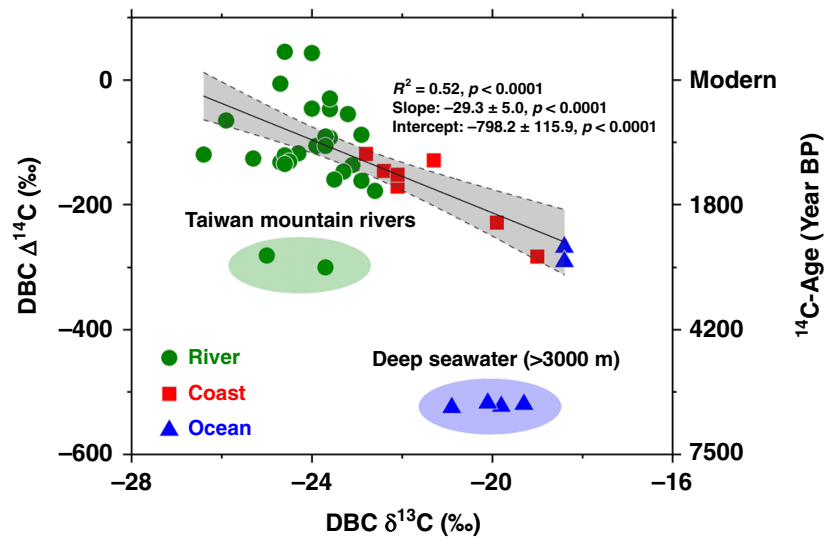

Fig. 5 Integrated isotopic correlation of DBC. Plot of $\Delta{ }^{14} \mathrm{C}$ vs. $\delta^{13} \mathrm{C}$ values of DBC (dissolved black carbon) measured in the four rivers (Yangtze, Yellow, Pearl, and Heilongjiang), the Yangtze and Yellow river estuaries, the East China Sea (ECS) and the Mariana Trench site in the North Pacific. The statistics are for the regression of the average values $(n=34$, the Taiwan mountain river and deep seawater data not included). We applied onesided $F$ test and two-sided $t$ test and the gray area shows the 95\% confidence interval of the linear regression with $p$ values as shown.

the results reported recently by Wagner et al. ${ }^{24}$, who found that oceanic DBC was approximately 6-8\% more enriched in $\delta^{13} \mathrm{C}$ than riverine DBC. Based on the $\delta^{13} \mathrm{C}$ differences, they concluded that oceanic DBC was not derived from rivers, so the DBC in rivers and oceans originates from different sources. As discussed above for the ${ }^{14} \mathrm{C}$ ages, we believe that $\mathrm{DBC}$ in the ocean is likely transported mainly by rivers through estuaries and coasts into the open ocean as a continuum, considering that the major pathways mobilizing and transporting DBC (27 Pg per year) from the land to the ocean are rivers $12,25,27,28$, compared to the rather smaller source of DBC (0.002-0.006 Gt per year) derived from atmospheric deposition in the Northern Hemisphere ${ }^{33}$. Clearly, what happens to the riverine $\mathrm{DBC}$ in the ocean and the causes of the different $\mathrm{DBC} \delta^{13} \mathrm{C}$ in rivers and ocean remain interesting questions, which need to be further studied.

Our long-team charcoal leaching experiments clearly demonstrated two important processes: (1) DBC was leached out from charcoal and dissolved in DOC with time, and (2) the released DBC was degraded by bacteria (Fig. 2). If we assume that $322 \mu \mathrm{M}$ (as measured in the bacteria-inhibited case) was also leached out from the charcoal in the bacteria-active case, then this amount of DBC was completely degraded by bacteria. The measured DOC $\Delta^{14} \mathrm{C}$ values provided good evidence that no modern $\mathrm{DBC}$ was added to the DOC $(-170 \%)$ at the end of the experiment based on the initial DOC $\Delta^{14} \mathrm{C}$ value $(-166 \%)$. In contrast to the bacteria-active case, when bacterial activities were inhibited, the DOC $\Delta^{14} C$ value $(-90 \%)$ was significantly increased at the end of the experiment. Based on the ${ }^{14} \mathrm{C}$ mass balance and assuming that the DBC released from the wood charcoal had a modern $\Delta^{14} \mathrm{C}$ value of $20 \%, 41 \%$ of the modern DBC was added to the DOC pool at the end of the bacteria-inhibited experiment, which was somehow lower than the $48 \%$ calculated from the increased DOC concentration $(440-228 \mu \mathrm{M})$. This discrepancy could be because at the end of the bacteria-inhibited experiment, we also measured some bacteria $\left(2.8 \times 10^{4} \mathrm{cell} \mathrm{mL}^{-1}\right)$ present in the water that consumed some DBC. For DOC $\delta^{13} \mathrm{C}$, the value in the bacteria-active water $(-25.1 \%$ ) was close to the original value $(-24.6 \%)$ but lower $(-27.8 \%)$ in the bacteria-inhibited water, which was close to the $\delta^{13} \mathrm{C}$ value of the locust tree wood charcoal $(-27.0 \%)$ used. These findings support the $\Delta^{14} \mathrm{C}$ results, indicating that $\mathrm{DBC}$ was leached from the charcoal and dissolved in DOC in the bacteria-inhibited case.
Our results provide direct evidence supporting the speculation that a large fraction of riverine DBC could be degraded in the estuaries and ocean ${ }^{9,24}$. Even though the dissolution of DBC is a slow process that is likely dynamically controlled by its watersolubility, this process could be significant in the natural environment because C-rich charcoal, a common residue of incomplete biomass combustion, is widely preserved in soils $s^{34,35}$, and a large fraction of this charcoal could be removed as DBC with time and transported by streams and rivers to the ocean ${ }^{28,36-39}$. The dominant $\mathrm{DBC}$ transported by the rivers is derived from biomass burning, and the DBC is labile and biodegradable. This could be the reason why we did not measure elevated DBC contents in the oceans. Our study suggests that $\mathrm{DBC}$ is unlikely to be a significant refractory DOC pool cycling in rivers and oceans, and DBC is likely aged on the same time scales as DOC cycling in the ocean.

\section{Methods}

Study sites and sample collection. Water samples used for this study were collected from four large rivers, namely, the Yangtze, Yellow, Pearl, and Heilongjiang rivers in China from 2015 to 2018 and from two small mountainous rivers (Dadu and Tamsui) in Taiwan in 2018. Samples were also collected from the Yangtze River and Yellow River estuaries, the ECS and the Mariana Trench site in the western North Pacific Ocean (NP) (Fig. 6). The detailed sampling locations and times are provided in Supplementary Table 1.

For the four rivers, in terms of the flow lengths, the Yangtze $(6300 \mathrm{~km})$, Yellow $(5464 \mathrm{~km})$, Heilongjiang $(4400 \mathrm{~km})$, and Pearl $(2300 \mathrm{~km})$ rivers rank as the four largest rivers in China, and the Yangtze River also ranks as the third longest river in the world. The drainage basins of these four rivers cover very different geographic environments from the southern subtropical warm climate to the far northern cold climate. The four rivers together drain $5.0 \times 10^{6} \mathrm{~km}^{2}$ of China's continental land and discharge $\sim 1688 \mathrm{~km}^{3} \mathrm{yr}^{-1}$ fresh water into the coastal seas. The two Taiwan mountainous rivers, Dadu and Tamsui, are relatively small $(\sim 200 \mathrm{~km})$. In total, 13 sites were sampled along the rivers: 5 from the Yangtze River, 2 from the Pearl River, 1 from the Yellow River, 3 from the Heilongiiang River, and 1 each from the Dadu and Tamsui rivers. The Yellow River site was sampled monthly for a year in $2015^{26,40}$ and sampled again in June 2020. In addition to river sampling, seven samples (C3, C5, A6-1, A6-3, P02, P04, and P06) were collected from the Yangtze River Estuary and the ECS using an in situ pump (SFP-900P) on board the R/V Dongfanghong 2 in $2015^{26,40}$, and three samples (YRE-1, YRE-2, and YRE-3) were collected from the Yellow River and estuary on board a small R/V Xinda-18 on June 2, 2020 (Fig. 6). For the Mariana Trench site $\left(11^{\circ} 20.605^{\prime} \mathrm{N}, 142^{\circ} 19.557^{\prime} \mathrm{E}\right.$; $10,800 \mathrm{~m})$ in the NP, water samples were collected at six depths $(50,100,3000$, 6000,8000 , and 10,000 m) aboard R/V Dongfanghong 2 during a February-March 2017 cruise $^{41}$.

At each site along the rivers and estuaries, 10-20 L of river water was collected using a precleaned stainless-steel bucket (washed with hot soapy water and rinsed with acid and Milli-Q water) in the main channel using a small boat (except for the Yellow River site where water was collected from a floating bridge, and the two small mountainous rivers in Taiwan where samples were collected by wading into the water). After collection, water was filtered through precombusted $\left(550^{\circ} \mathrm{C}\right.$ for $4 \mathrm{~h}) 0.7 \mu \mathrm{m}$ pore size GF/F filters and acidified to $\mathrm{pH}=2$ with high-purity $\mathrm{HCl}$. Seawater samples were collected using $12 \mathrm{~L}$ Niskin bottles attached to a rosette sampler with conductivity, temperature, and depth sensors. Approximately, $30 \mathrm{~L}$ was collected from the Yangtze River Estuary and the ECS sites, and $50 \mathrm{~L}$ was collected from each depth at the Mariana Trench site. After collection, seawater was also filtered immediately and acidified to $\mathrm{pH}=2$. The acidified water samples were stored in precleaned polyethylene bottles at low temperature for further processing.

SPE-DOC extraction. In the laboratory, acidified river and ocean water samples were extracted for DOC using the SPE method ${ }^{42}$. We used prepacked $60-\mathrm{mL}$ volume PPL cartridges (Agilent Technologies Mega Bond Elute) that contained $5 \mathrm{~g}$ styrene divinyl benzene polymer as the sorbent (pore size $150 \AA$ ) with the capacity to process a large volume of water samples ${ }^{40}$. Before extraction, the cartridge was well cleaned according to the manufacturer's guidelines. It was first rinsed with two bed volumes of high-purity methanol (B\&J), followed by at least $2000 \mathrm{~mL}$ Milli-Q pure water to clean the sorbent free of OC (measured for DOC) ${ }^{40}$. Water samples were placed in a 2 -L glass funnel, dropped directly into the top of the cleaned PPL cartridge, and passed through at a flow rate of $5 \mathrm{~mL} / \mathrm{min}^{40}$. The permeate passing through the cartridge was frequently collected for DOC analyses to determine the extraction efficiencies (calculated based on the DOC concentration difference between water sample and permeate). Overall, there were average values of $61 \pm 6 \%$ for riverine DOC, $51 \pm 11 \%$ for estuarine and coastal DOC and $47 \pm 4 \%$ for ocean DOC (Supplementary Table 2).

After extraction, the cartridge sorbent was rinsed with one bed volume of $0.01 \mathrm{M} \mathrm{HCl}$ twice to remove salts and then dried with high-purity nitrogen gas. 


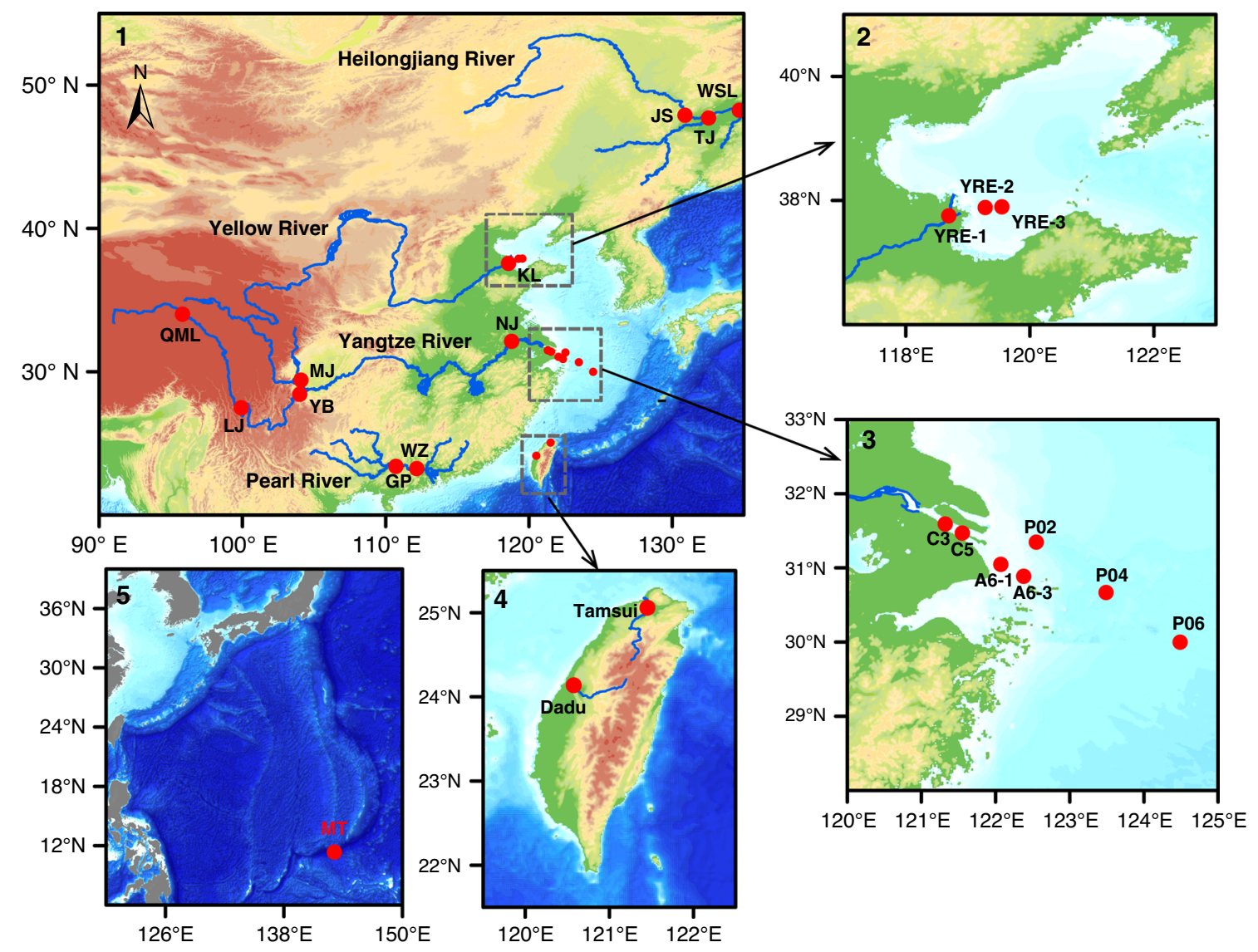

Fig. 6 Map of the study sites and sampling locations. Sampling sites (1) in the four major continental rivers (Pearl, Yangtze, Yellow, and Heilongjiang) in China; (2) the three sites in the Yellow River Estuary; (3) the seven sites in the Yangtze River Estuary and the East China Sea (ECS); (4) the two sites in the two mountainous rivers in Taiwan; and (5) the Mariana Trench (MT) site $\left(11^{\circ} 20.605^{\prime} \mathrm{N}, 142^{\circ} 19.557^{\prime} \mathrm{E}\right)$ in the western North Pacific Ocean.

Once the cartridge was dry, $80 \mathrm{~mL}$ high-purity methanol was used to elute the DOC extracted from the sorbent. We determined that $>98 \%$ of DOC absorbed on the sorbent was eluted in the methanol phase ${ }^{40}$. The extracted DOC in methanol was then condensed to $5 \mathrm{~mL}$ using a Buchi Multivapor P-12 Evacuator. The condensed DOC was defined as SPE-DOC and stored in a refrigerator for further $\mathrm{DBC}$ and isotope determination. All glassware used in sample processing and storage was soaked in $10 \% \mathrm{HCl}$ acid for $24 \mathrm{~h}$, rinsed with Milli-Q water and baked at $550^{\circ} \mathrm{C}$ for $5 \mathrm{~h}$ to remove any OC prior to use. Blanks associated with SPE extraction were determined. We considered two types of blanks during the extraction: a sorbent blank and a methanol elution blank. To test the blanks from the sorbent, we continuously collected Milli-Q water permeate for every $500 \mathrm{~mL}$ that passed through the precleaned cartridge for the same extraction volume $(15 \mathrm{~L})$ to measure DOC concentrations. To check the blanks during methanol elution, we collected $80 \mathrm{~mL}$ of methanol eluent, dried it with high-purity $\mathrm{N}_{2}$ gas, redissolved it in high-purity Milli-Q water, and measured its DOC concentration. In both cases, we found no detectible DOC (below the detection limit of $\sim 3 \mu \mathrm{M}$ ) associated with either the sorbent or methanol ${ }^{40}$, consistent with the results reported in previous studies ${ }^{42,43}$

DBC isolation and measurement. The concentrations of DBC in the SPE-DOC were determined by the thermal oxidation method ${ }^{21,44}$. For DBC analysis,

1.0-2.0 mL of condensed SPE-DOC was added to a 9-mm outer diameter (OD) $\times$ 200-mm quartz tube (prebaked at $850^{\circ} \mathrm{C}$ for $2 \mathrm{~h}$ ) and dried with high-purity $\mathrm{N}_{2}$. The quartz tube was then placed in an oven, and the SPE-DOC was thermally oxidized at $375^{\circ} \mathrm{C}$ for $24 \mathrm{~h}$ with a continuous air supply to remove non-BC OC. The OC left after thermal oxidation was defined as DBC. Following thermal oxidation, $\mathrm{DBC}$ was oxidized again in evacuated, flame-sealed quartz tubes (with $\mathrm{CuO}$ and $\mathrm{Ag}$ wire added) at $850^{\circ} \mathrm{C}$ for $2 \mathrm{~h}$ in a muffle furnace. The resultant $\mathrm{CO}_{2}$ from combustion was collected cryogenically and quantitatively measured on a vacuum line. The amounts of DBC were calculated based on the volume of the resultant $\mathrm{CO}_{2}$.

To test the possibility that some non-BC DOC could be converted to DBC during thermal oxidation, we used three concentrated $(10-15 \mathrm{mM})$ DOC samples: DOC leached from fresh salt marsh plants Phragmites australis and Suaeda salsa collected in the Yellow River Delta 45 and DOC released from coastal phytoplankton collected in the ECS. One milliliter of each DOC was acidified and dried in a $9-\mathrm{mm} \mathrm{OD} \times 200-\mathrm{mm}$ quartz tube in triplicate and thermally oxidized at $375^{\circ} \mathrm{C}$ for $24 \mathrm{~h}$, the same as for the DBC treatment as described above. For all three DOC samples, we did not detect any measurable DBC converted from fresh DOC by the thermal oxidation method.

DOC analysis. The concentration of DOC was analyzed by the high-temperature catalytic oxidation method using a Shimadzu TOC-L analyzer equipped with an ASI-L autosampler. The instrument was calibrated using 5-point calibration curves derived from a carbon standard solution of potassium hydrogen phthalate, and DOC values were checked against low carbon water and deep seawater reference materials (CRM, University of Miami, Rosenstiel School of Marine and Atmospheric Sciences). Blank subtraction was carried out using high-purity Milli-Q water that was analyzed before every five samples. The average blanks associated with DOC measurements were approximately $4 \mu \mathrm{M}$, and the analytic precision on triplicate injections was $<3 \% 31$.

Carbon isotope analyses. Carbon isotopes $\left(\Delta^{14} \mathrm{C}\right.$ and $\left.\delta^{13} \mathrm{C}\right)$ were analyzed for DOC, SPE-DOC, and DBC. SPE-DOC and DBC were dried and combusted in evacuated 9-mm OD quartz tubes, and the resultant $\mathrm{CO}_{2}$ was collected cryogenically on a vacuum line as described above. The purified $\mathrm{CO}_{2}$ was flame-sealed in a 6-mm OD glass tube for isotope analysis. The bulk DOC of the samples was processed separately using a modified UV oxidation method for carbon isotope measurement ${ }^{46}$. Briefly, approximately $200 \mathrm{~mL}$ (river) or $400 \mathrm{~mL}$ (seawater) of acidified water was placed into $2-4$ custom-made $100-\mathrm{mL}$ quartz reaction tubes specially designed to interface directly with a vacuum extraction line. Samples were first purged with ultrahigh purity (UHP) helium gas for $30 \mathrm{~min}$ to remove dissolved inorganic carbon and then irradiated using a $1.2 \mathrm{~kW}$ medium-pressure mercury arc UV lamp (Hanovia $\mathrm{Co}$.) for $5 \mathrm{~h}$. Following UV irradiation, $\mathrm{CO}_{2}$ generated from UV oxidation of DOC was purged again with UHP helium gas through the vacuum line and collected cryogenically and measured manometrically. The purified $\mathrm{CO}_{2}$ was flame-sealed in 6-mm OD Pyrex tubes for $\delta^{13} \mathrm{C}$ and $\Delta^{14} \mathrm{C}$ analyses. The oxidation efficiency and blanks associated with the UV oxidation of DOC were tested using high-purity Milli-Q water and a DOC (oxalic acid OXI) standard solution, yielding high oxidation efficiency $(\sim 95 \%)$ for DOC and considerably low blanks $(<4 \mu \mathrm{g} \mathrm{C})^{46}$.

The $\delta^{13} \mathrm{C}$ and $\Delta^{14} \mathrm{C}$ measurements were performed at the National Ocean Sciences Accelerator Mass Spectrometry (NOSAMS) facility at the Woods Hole Oceanographic Institution (WHOI) in the USA and the Center for Isotope 
Geochemistry and Geochronology (CIGG) of the Qingdao National Laboratory for Marine Science and Technology (QNLM) in Qingdao, China. Sample $\delta^{13} \mathrm{C}$ was analyzed using a Thermo 253-Plus isotope ratio mass spectrometer (IRMS) with a dual inlet at CIGG. The data reduction of $\delta^{13} \mathrm{C}$ values was performed using International Atomic Energy Agency (IAEA) isotope standards (IAEA-CH-3 Cellulose and IAEA-600 Caffeine), measured in \%o with analytic precision of $\leq 0.2 \%$. Purified $\mathrm{CO}_{2}$ samples (>100 $\mu \mathrm{g} \mathrm{C}$ ) were first graphitized using a sealed tube zinc reduction method ${ }^{47}$, and ${ }^{14} \mathrm{C}$ was analyzed using AMS. The $\Delta^{14} \mathrm{C}$ results were reported as fraction modern, and the conventional radiocarbon ages (YBP) were calculated based on Stuiver and Polach ${ }^{48}$. All $\Delta^{14} \mathrm{C}$ results were corrected for $\delta^{13} \mathrm{C}$ fractionation and for ${ }^{14} \mathrm{C}$ decay for the time period between 1950 and the year of sample collection.

DBC dissolution and degradation experiment. To test the dynamics of dissolution and biodegradation of DBC in rivers, we conducted long-term leaching experiments using freshly burned locust tree wood charcoal. The charcoal was obtained from a countryside family who used locust tree wood for cooking (see the charcoal image in Supplementary Fig. 1). We added $200 \mathrm{mg}$ of charcoal (ground to $100-200 \mu \mathrm{m}$ size) each into two 1-1 glass bottles filled with filtered Yellow River water (collected in October 2015). In one bottle, $2.0 \mathrm{~mL}$ of saturated $\mathrm{HgCl}_{2}$ solution was added to eliminate bacterial activity (bacteria inhibited) and to compare the charcoal leaching process with the bacteria-active bottle. The bottles were covered loosely and incubated undisturbed at room temperature in the dark. During the incubation, the ground charcoal all deposited on the bottom, we left the bottles disturbed and no air or oxygen was bubbled into the water during the entire incubation period. Subsamples $(10 \mathrm{~mL})$ were collected from each bottle using a glass syringe at different times and were filtered with a precleaned $0.45 \mu \mathrm{m}$ cellulose acetate membrane attached to a syringe for DOC concentration measurement. We assume that all DBC leached from the charcoal was dissolved in the water in the form of DOC. The leaching experiments were started in late October 2015, and after approximately 1000 days (June 30,2018 ), the bottles were capped and kept at room temperature for another 700 days (May 10, 2020). We filtered the water and measured the final concentrations of DOC and DOC $\Delta^{14} \mathrm{C}$ and the $\delta^{13} \mathrm{C}$ values as described above. We also measured the bacterial abundance in the waters.

The bacterial abundance was measured in the charcoal leaching experiment waters. Filtered water samples $(10 \mathrm{~mL})$ were fixed with $2 \%$ paraformaldehyde $(1: 1$ vol.) and stored at $-80{ }^{\circ} \mathrm{C}$ before use. For bacterial abundance quantification, the samples were thawed at room temperature and then stained with $0.01 \%$ SYBR Green I (Invitrogen, CA, USA) at $37^{\circ} \mathrm{C}$ for $1 \mathrm{~h}$ in the dark ${ }^{49}$. Yellowish green fluorescence beads $(1 \mu \mathrm{m}$, Polysciences Inc., PA, USA) were added as an internal standard to calibrate and normalize the fluorescence and light scattering signals. Cell counting was conducted using a CytoFLEX flow cytometer (Beckman Coulter) equipped with a $488 \mathrm{~nm}$ argon laser (Supplementary Fig. 2). As a remedial measure, we measured the bacterial abundance in fresh Yellow River water collected at the same site on June 2, 2020 and assumed that the bacterial abundance was similar in the river water we used for the experiments.

\section{Data availability}

All data for this study are available in Supplementary Table 2 associated with the paper. The data will be publicly available on the Figshare data repository at https://doi.org/ 10.6084/m9.figshare.12774689.

Received: 13 March 2020; Accepted: 15 September 2020; Published online: 07 October 2020

\section{References}

1. Goldberg, E. D. Black Carbon in the Environment: Properties and Distribution. (Wiley \& Sons, New York, 1985).

2. Masiello, C. \& Druffel, E. R. M. Black carbon in deep-sea sediments. Science 280, 1911-1913 (1998)

3. Landry, J. S. \& Matthews, H. D. The global pyrogenic carbon cycle and its impact on the level of atmospheric $\mathrm{CO}_{2}$ over past and future centuries. Glob. Change Biol. 23, 3205-3218 (2017).

4. Abney, R. B. \& Berhe, A. A. Pyrogenic carbon erosion: implications for stock and persistence of pyrogenic carbon in soil. Front. Earth Sci. https://doi.org/ 10.3389/feart.2018.00026 (2018).

5. Santín, C., Doerr, S. H., Perston, C. M. \& Gonzalez-Rodríguez, G. Pyrogenic organic matter production from wild fires: a missing sink in the global carbon cycle. Glob. Change Biol. 21, 1621-1633 (2015).

6. Coppola, A. I. et al. Marked isotopic variability within and between the Amazon River and marine dissolved black carbon pools. Nat. Commun. 10, 4018 (2019).

7. Fang, Y. et al. Large-river dominated black carbon flux and budget: a case study of the estuarine-inner shelf of East China Sea, China. Sci. Total. Environ. 651, 2489-2496 (2019)
8. Jones, M. W. et al. Environmental controls on the riverine export of dissolved black carbon. Glob. Biogeochem. Cycles 33, 849-874 (2019).

9. Coppola, A. I. et al. Global-scale evidence for the refractory nature of riverine black carbon. Nat. Geosci. 11, 584-588 (2018).

10. Coppola, A. I. \& Druffel, E. R. M. Cycling of black carbon in the ocean Geophys. Res. Lett. 43, 4477-4482 (2016).

11. Ziolkowski, L. A. \& Druffel, E. R. M. Aged black carbon identified in marine dissolved organic carbon. Geophys. Res. Lett. 37, L16601 (2010).

12. Jaffé, R. et al. Global charcoal mobilization from soils via dissolution and riverine transport to the oceans. Science 340, 345-347 (2013).

13. Jones, M. W., Santin, C., van der Werf, G. R. \& Doerr, S. H. Global fire emissions buffered by the production of pyrogenic carbon. Nat. Geosci. 12, 742-747 (2019).

14. Reisser, M., Purves, R. S., Schmidt, M. W. \& Abiven, S. Pyrogenic carbon in soils: a literature-based inventory and a global estimation of its content in soil organic carbon and stocks. Front. Earth Sci. 4, 80 (2016).

15. Bird, M. I., Moyo, C., Veenendaal, E. M., Lloyd, J. \& Frost, P. Stability of elemental carbon in a savanna soil. Glob. Biogeochem. Cycles 13, 923-932 (1999).

16. Singh, N. et al. Transformation and stabilization of pyrogenic organic matter in a temperate forest field experiment. Glob. Change Biol. 20, 1629-1642 (2014).

17. Dittmar, T. \& Koch, B. P. Thermogenic organic matter dissolved in the abyssal ocean. Mar. Chem. 102, 208-217 (2006)

18. Zigah, P. K. et al. Allochthonous sources and dynamic cycling of ocean dissolved organic carbon revealed by carbon isotopes. Geophy. Res. Lett. $\mathbf{4 4}$ 2407-2415 (2017)

19. Schmidt, M. W. I. et al. Comparative analysis of black carbon in soils. Glob. Biogeochem. Cycles 15, 163-167 (2001).

20. Hammes, K. et al. Comparison of quantification methods to measure firederived (black/elemental) carbon in soils and sediments using reference materials from soil, water, sediment and the atmosphere. Glob. Biogeochem. Cycles 21, GB3016 (2007).

21. Gustafsson, Ö. et al. Evaluation of a protocol for the quantification of black carbon in sediments. Glob. Biogeochem. Cycles 15, 881-890 (2001).

22. Reddy, C. M. et al. Radiocarbon as a tool to apportion the sources of polycyclic aromatic hydrocarbons and black carbon in environmental samples. Environ. Sci. Technol. 36, 1774-1782 (2002).

23. Zencak, Z., Elmquist, M. \& Gustafsson, Ö. Quantification and radiocarbon source apportionment of black carbon in atmospheric aerosols using the CTO-375 method. Atmos. Environ. 41, 7895-7906 (2007).

24. Wagner, S. et al. Isotopic composition of oceanic dissolved black carbon reveals non-riverine source. Nat. Commun. 10, 5064 (2019).

25. Dittmar, T., Paeng, J., Gihring, T. M., Suryaputra, A. \& Huettel, M. Discharge of dissolved black carbon from a fire-affected intertidal system. Limnol. Oceanogr. 57, 1171-1181 (2012)

26. Wang, X., Xu, C., Druffel, E. M., Xue, Y. \& Qi, Y. Two black carbon pools transported by the Changiiang and Huanghe Rivers in China. Glob. Biogeochem. Cycles 30, 1778-1790 (2016).

27. Lewis, C. B., Walker, B. D. \& Druffel, E. R. M. Isotopic and optical heterogeneity of solid phase extracted marine dissolved organic carbon. Mar. Chem. 219, 103752 (2020).

28. Ding, Y., Yamashita, Y., Jones, J. \& Jaffe, R. Dissolved black carbon in boreal forest and glacial rivers of central Alaska: assessment of biomass burning versus anthropogenic sources. Biogeochemistry 123, 15-25 (2015).

29. Druffel, E. R. M., Bauer, J. E., Griffin, S., Beaupré, S. R. \& Hwang, J. Dissolved inorganic radiocarbon in the North Pacific Ocean and Sargasso Sea. Deep Sea Res. Part I 55, 451-459 (2008).

30. Druffel, E. R. M., Griffin, S., Coppola, A. I. \& Walker, B. D. Radiocarbon in dissolved organic carbon of the Atlantic Ocean. Geophy. Res. Lett. 43, 5279-5286 (2016).

31. Xue, Y. J., Zou, L., Ge, T. T. \& Wang, X. C. Mobilization and export of millennialaged organic carbon by the Yellow River. Limnol. Oceanogr. 62, S95-S111 (2017).

32. Wang, X. C., Ma, H. Q., Li, R. H., Song, Z. S. \& Wu, J. P. Seasonal fluxes and source variation of organic carbon transported by two major Chinese Rivers: the Yellow River and Changjiang (Yangtze) River. Glob. Biogeochem. Cycles 26, GB2025 (2012).

33. Jurado, E., Dachs, J., Duarte, C. M. \& Simo, R. Atmospheric deposition of organic and black carbon to the global oceans. Atmos. Environ. 42, 7931-7939 (2008).

34. Czimczik, C. I. \& Masiello, C. A. Controls on black carbon storage in soils. Glob. Biogeochem. Cycles 21, GB3005 (2007).

35. Cusack, D. F., Chadwick, O. A., Hockaday, W. C. \& Vitousek, P. M. Mineralogical controls on soil black carbon preservation. Glob. Biogeochem. Cycles 26, GB2019 (2012).

36. Wagner, S., Cawley, K. M., Rosario-Ortiz, F. L. \& Jaffé, R. In-stream sources and links between particulate and dissolved black carbon following a wildfire. Biogeochemistry 124, 145-161 (2015).

37. Bao, H., Niggemann, J., Huang, D., Dittmar, T. \& Kao, S. J. Different responses of dissolved black carbon and dissolved lignin to seasonal hydrological changes and an extreme rain event. J. Geophys. Res. 124, 479-493 (2019). 
38. Ding, Y., Yamashita, Y., Dodds, W. K. \& Jaffe, R. Dissolved black carbon in grassland streams: is there an effect of recent fire history? Chemosphere $\mathbf{9 0}$ 2557-2562 (2013).

39. Wagner, S., Ding, Y. \& Jaffé, R. A new perspective on the apparent solubility of dissolved black carbon. Front. Earth Sci. https://doi.org/10.3389/ feart.2017.00075 (2017).

40. Xu, C. L., Xue, Y. J., Qi, Y. Z. \& Wang, X. C. Quantities and fluxes of dissolved and particulate black carbon in the Changjiang and Huanghe Rivers. China Estuar. Coast. 39, 1617-1625 (2016).

41. Shan, S. et al. Carbon cycling in the Mariana Trench in the western North Pacific Ocean: insights from radiocarbon proxy data. Deep Sea Res. I https:// doi.org/10.1016/j.dsr.2020.103370 (2020).

42. Dittmar, T., Koch, B., Hertkorn, N. \& Kattner, G. A simple and efficient method for the solid-phase extraction of dissolved organic matter (SPE-DOM) from seawater. Limnol. Oceanogr. Methods 6, 230-235 (2008).

43. Dittmar, T. The molecular level determination of black carbon in marine dissolved organic matter. Org. Geochem. 39, 396-407 (2008).

44. Gustafsson, Ö. \& Gschwend, P. M. The flux of black carbon to surface sediments on the New England continental shelf. Geochim. Cosmochim. Acta 62, 465-472 (1998).

45. Zhang, T. \& Wang, X. C. Stable carbon isotope and long-chain alkane compositions of the major plants and sediment organic matter in the Yellow River Estuarine wetlands. J. Ocean Univ. China 18, 1-8 (2018).

46. Xue, Y., Ge, T. \& Wang, X. An effective method of UV-oxidation of dissolved organic carbon in natural waters for radiocarbon analysis by accelerator mass spectrometry. J. Ocean Univ. China 14, 989-993 (2015).

47. $\mathrm{Xu}, \mathrm{X}$. M. et al. Modifying a sealed tube zinc reduction method for preparation of AMS graphite targets: reducing background and attaining high precision. Nucl. Instrum. Methods B 259, 320-329 (2007).

48. Stuiver, M. \& Polach, H. A. Discussion reporting of ${ }^{14} \mathrm{C}$ data. Radiocarbon 19, 355-363 (1977).

49. Marie, D., Partensky, F., Jacquet, S. \& Vaulot, D. Enumeration and cell cycle analysis of natural populations of marine picoplankton by flow cytometry using the nucleic acid stain SYBR Green I. Appl. Environ. Microbiol. 63, 186-193 (1997).

\section{Acknowledgements}

We thank the members of our laboratory for helping with the sample collection and processing and chemical analyses. We give special thanks to the staff of NOSAMS at WHOI and CIGG at QNLM for providing high-precision isotope measurements of the samples. This study was financially supported by the National Natural Science Foundation of China (Grants \# 91858210, 41776082, and 91428101) and the Fundamental Research Funds for the Central Universities (grant \# 201762009).

\section{Author contributions}

$\mathrm{X} . \mathrm{W}$. conceptualized and led the studies, participated in the river sampling and data analysis and wrote the paper; Y.Q., W.F., C.L., S.S., P.R., and H.Z. collected the river, estuarine, and E.C.S. samples and processed the DOC, SPE, and DBC. data; J.T. and X.Z. collected the samples from the Mariana Trench in the North Pacific; J.L. and X.Z. analyzed the bacterial abundances; and S.S. performed the sample isotope analysis. All authors provided comments and contributed to the final version of the paper.

\section{Competing interests}

The authors declare no competing interests.

\section{Additional information}

Supplementary information is available for this paper at https://doi.org/10.1038/s41467020-18808-8.

Correspondence and requests for materials should be addressed to X.W.

Peer review information Nature Communications thanks Yingjun Chen and other, anonymous, reveiwers for their contributions to the peer review of this work. Peer review reports are available.

Reprints and permission information is available at http://www.nature.com/reprints Publisher's note Springer Nature remains neutral with regard to jurisdictional claims in published maps and institutional affiliations.

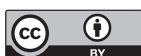

Open Access This article is licensed under a Creative Commons Attribution 4.0 International License, which permits use, sharing, adaptation, distribution and reproduction in any medium or format, as long as you give appropriate credit to the original author(s) and the source, provide a link to the Creative Commons license, and indicate if changes were made. The images or other third party material in this article are included in the article's Creative Commons license, unless indicated otherwise in a credit line to the material. If material is not included in the article's Creative Commons license and your intended use is not permitted by statutory regulation or exceeds the permitted use, you will need to obtain permission directly from the copyright holder. To view a copy of this license, visit http://creativecommons.org/ licenses/by/4.0/.

(C) The Author(s) 2020 